\title{
PENGARUH BUDAYA ORGANISASI, KOMPENSASI NON FINANSIAL, DAN JOB INSECURITY TERHADAP TURNOVER INTENTION PADA PT. BPR CINCIN PERMATA ANDALAS CABANG PADANG
}

\author{
Deby Gusti Ayu, Riri Mayliza \\ Sekolah Tinggi Ilmu Ekonomi KBP \\ ririmayliza@akbpstie.ac.id
}

\begin{abstract}
ABSTRAK
Untuk mengetahui budaya organisasi, kompensasi non finansial, dan job insecurity terhadap turnover intention karyawan pada PT. BPR Cincin Permata Andalas Cabang Padang. Jenis Penelitian yang digunakan pada penelitian ini adalah penelitian kuantitatif. Berdasarkan hasil pengujian dari hipotesis ditemukan bahwa: 1) Berdasarkan hasil uji t pada variabel budaya organisasi sebesar $-0,005$ dan tidak signifikansinya sebesar 0,996 yang lebih besar dari 0,05. dalam penelitian ini yang menyatakan bahwa budaya organisasi berpengaruh negatif dan tidak signifikan terhadap turnover intention pada PT. BPR Cincin permata andalas padang, dinyatakan ditolak. 2) Berdasarkan hasil uji t variabel kompensasi non finansial sebesar 2.334 dan signifikansinya sebesar 0,028 yang lebih kecil dari 0,05. dengan demikian, hipotesis kedua (H2) dalam penelitian ini yang menyatakan bahwa kompensasi non finansial berpengaruh positif dan signifikan terhadap turnover intention pada PT. BPR Cincin Permata Andalas dapat diterima. 3) Berdasarkan hasil uji t variabel job insecurity sebesar 3.157 dan signifikansinya sebesar 0,004 yang lebih kecil dari 0,05. dengan demikian, hipotesis ketiga $(\mathrm{H} 3)$ dalam penelitian ini yang menyatakan bahwa job insecurity berpengaruh positif dan signifikan terhadap turnover intention pada PT. BPR Cincin Permata Andalas dapat diterima.
\end{abstract}

Kata Kunci: budaya organisasi, kompensasi non finansial, job insecurity, turnover intention

\section{PENDAHULUAN}

Peranan perbankan sangat penting dalam bidang perekonomian semakin meningkatkan kebutuhan masyarakat maupun pemerintah. Perkembangan perbankan di suatu negara dapat dijadikan sebagai tolak ukur kemajuan dari negara tersebut. Bank dibagi dalam beberapa jenis. Ditinjau dari segi fungsi, jenisjenis bank yaitu Bank Sentral, Bank Umum, dan Bank Perkreditan Rakyat. Bank Sentral merupakan bank yang mengatur berbagai kegiatan yang berkaitan dengan dunia perbankan dan keuangan disuatu negara. Bank Umum merupakan bank yang bertugas melayani seluruh jasa-jasa perbankan dan melayani seluruh lapisan 
masyarakat. Bank Perkreditan Rakyat (BPR) merupakan Bank yang khusus melayani masyarakat kecil (menengah Bawah).

Bank Perkreditan Rakyat (BPR) sebagai salah satu perusahaan yang bergerak dibidang perbankan yang berbadan hukum adalah salah satu jenis lembaga usaha perbankan yang mempunyai peranan penting dalam melayani kepentingan dan kebutuhan masyarakat dibidang jasa keuangan, khususnya untuk Usaha Kecil dan Mikro (UKM). Oleh sebab itu BPR harus selalu meningkatkan kinerjanya sehingga tumbuh dengan sehat dan dapat melaksanakn fungsi intermediasinya sesuai dengan yang diharapkan kelompok sasarannya dan masyarakat lain pada umumnya. Turnover mengarah pada kenyataan akhir yang dihadapi yang dihadapi organisasi berupa jumlah karyawan yang meninggalkan organisasi pada periode tertentu, sedangkan turnover intention mengacu pada hasil evaluasi individu mengenai kelanjutan hubungan organisasi dan belum diwujudkan dalam tindakan pasti meninggalkan organisasi. Turnover dapat berupa pengunduran diri, perpindahan keluar unit organisasi, pemberhentian atau kematian anggota organisasi. Tingkat turnover karyawan yang tinggi merupakan ukuran yang sering digunakan sebagai indikasi adanya masalah yang mendasar pada organisasi. Turnover karyawan dapat menciptakan ketidakstabilan dan ketidakpastian terhadap kondisi karyawan, juga peningkatan biaya rekrutmen.

Menurut Saputra (2017), budaya sebagai suatu asumsi-asumsi dan keyakinan-keyakinan dasar yang dirasakan bersama oleh para anggota dari suatu kelompok dan organisasi. Dengan demikian budaya organisasi dapat diartikan sebagai suasana atau keadaan dalam suatu kelompok kerjasama antara orangorang tergabung di dalamnya untuk mencapai tujuan bersama. Organisasi dapat menerapkan budaya organisasinya dengan secara baik juga, sehingga setiap anggota organisasi dapat bekerja sama secara maksimal karena penerapan budaya yang baik dalam setiap organisasi sangat penting dan harus diterapkan, karena budaya organisasi bukan merupakan suatu peraturan yang harus dijalani melainkan kesadaran dari tiap anggota untuk menyadari apa yang harus dikerjakan untuk mencapai tujuan bersama dan tujuan dari perusahaan, sehingga dapat mengurangi turnover dari karyawan.

Menurut Yudith et al (2015), Kompensasi adalah segala sesuatu yang telah diberikan kepada karyawan sebagai balas jasa atas kontribusi tenaga dan pikiran yang telah mereka sumbangkan kepada organisasi dimana mereka bekerja. Kompensasi dapat digunakan untuk memikat dan mempertahankan karyawan pada perusahaan. Kompensasi merupakan tanggung jawab dari perusahaan sebagai penyedia pekerja dan merupakan hak bagi karyawan sebagai bentuk balas jasa atas kontribusinya kepada perusahaan.

Upah atau gaji merupakan sejumlah upah yang diterima dan dirasakan adil, bersifat finansial seperti tunjangan finansial seperti tunjangan hari tua (pensiun), bonus, dan honor, ada pula yang bersifat non finansial seperti program rekreasi dan piknik bagi karyawan. Dalam kebanyakan hal, program tunjangan diberikan atas senioritas dan kehadiran. Pekerjaan (work itself) merupakan tugastugas pekerjaan yang dianggap menarik dan memberikan kesempatan untuk belajar serta bertanggung jawab untuk karyawan yang bersangkutan. Promosi karir (promotion opportunities) merupakan tersedianya kesempatan untuk 
kenaikan jabatan. Kelompok kerja (co-workers) merupakan rekan-rekan kerja yang menunjukkan sikap bersahabat dan saling mendukung antara satu dengan yang lainnya. Kondisi kerja (working conditions) merupakan kondisi lingkungan kerja fisik yang nyaman atau tidak nyaman dan dapat mendukung produktivitas dalam bekerja, dan rasa aman/tidak aman dalam bekerja (job Insecurity) merupakan keyakinan individu bahwa posisi jabatan tidak aman, rasa khawatir, dan putusnya harapan bahwa adanya pemutusan kerja secara sepihak.

Menurut Saputra (2017), job insecurity adalah kondisi psikologis seseorang (karyawan) yang menunjukkan rasa bingung atau merasa tidak aman dikarenakan kondisi lingkungan yang berubah ubah. Makin banyaknya jenis pekerjaan dengan durasi waktu yang sementara atau tidak permanen, menyebabkan semakin banyaknya karyawan yang mengalami job insecurity hal ini bisa terjadi disetiap organisasi manapun. Dengan adanya hal ini perusahaan harus memperhatikan setiap karyawannya.

Jadi dapat disimpulkan job insecurity adalah kondisi ketika karyawan merasakan ketidakpastian terhadap pekerjaan dan kompensasi yang diperoleh dimasa yang akan datang. Ketidakpastian pekerjaan tidak hanya berarti "khawatir akan kehilangan pekerjaan" saja, tetapi juga meliputi ketakutan kehilangan fasilitas yang bernilai dari suatu pekerjaan (value job features) seperti jabatan maupun kesempatan dipromosikan.

Menurut Yudith et al (2015), turnover intention adalah suatu proses dari keinginan sampai dengan memutuskan untuk keluar dari perusahaan dengan beberapa alasan. Tingginya tingkat turnover intention akan menjadi masalah serius bagi perusahaan karena pada akhirnya perusahaan harus kembali melakukan rekruitmen apabila karyawan yang ada memutuskan untuk keluar.

Berdasarkan latar belakang diatas permasalahan yang penulis buat adalah sebagai berikut: 1) Apakah budaya organisasi karyawan PT. BPR Cincin Permata Andalas Cabang Padang berpengaruh terhadap turnover intention?, 2) Apakah kompensasi non finansial yang diterima oleh karyawan PT. BPR Cincin Permata Andalas Cabang Padang berpengaruh terhadap turnover intention?. 3) Apakah job insecurity dapat terjadi pada karyawan pada PT. BPR Cincin Permata Andalas Cabang Padang terhadap turnover intention?

\section{LANDASAN TEORI \\ Turnover Intention}

Menurut Maulidah (2012), Turnover adalah berhentinya seorang karyawan dari tempatnya bekerja secara sukarela atau pindah dari satu tempat kerja ke tempat kerja lain. Niat karyawan untuk berhenti dari pekerjaannya secara sukarela ke tempat kerja lain menurut pilihannya sendiri. Menurut Mufidah (2016), turnover intentions mengacu kepada kemungkinan karyawan meninggalkan pekerjaan dan organisasi mereka atas kehendak sendiri. Ketika turnover meningkat, tingkat turnover dan absensi meningkat. Turnover adalah konsep yang diperhatikan oleh para peneliti mikro dan makro di tingkat kedisiplinan. Di tingkat makro melalui perspektif antara kepuasan. Menurut Wardani et al (2014), turnover intention merupakan kadar atau intensitas dari keinginan untuk keluar dari perusahaan. Keinginan ini akan mendorong terjadinya turnover karyawan. 
Tingginya tingkat turnover intention akan menjadi masalah serius untuk perusahaan karena pada akhirnya perusahaan harus kembali melakukan rekruitmen apabila karyawan yang ada memutuskan untuk keluar. Menurut Syafrizal (2011), turnover intention adalah kecenderungan sikap dan tingkat dimana seorang karyawan memiliki kemungkinan untuk meninggalkan organisasi atau mengundurkan diri secara sukarela dari pekerjaannya. Keinginan untuk pindah dapat dijadikan gejala awal terjadinya turnover dalam sebuah perusahaan. Intensi keluar (turnover intention) juga dapat diartikan sebagai pergerakan tenaga kerja keluar dari organsasi. Turnover dapat berupa pengunduran diri, perpindahan keluar unit organisasi, pemberhentian atau kematian organisasi. Menurut Sandi (2014), intense merupakan suatu indikasi dari kesiapan seseorang untuk menunjukkan perilaku, dan hal ini merupakan anteseden dari perilaku, sedangkan turnover intention mengacu pada niat seseorang untuk mencari alternatif pekerjaan lain dan belum terwujud dalam bentuk perilaku nyata. Jadi, turnover intention diindikasikan sebagai sikap individu yang mengacu pada hasil evaluasi mengenai kelangsungan hubungannya dengan organisasi dimana dirinya bekerja dan belum terwujud dalam bentuk tindakan pasti. Faktor-faktor terjadinya turnover intention bisa diindikasikan sebagai berikut :

1. Absensi yang meningkat

Karyawan yang berkeinginan untuk melakukan pindah kerja biasanya ditandai dengan absensi yang semakin meningkat. Tingkat tanggung jawab pada fase ini sangat kurang dibandingkan dengan sebelumnya

2. Mulai malas bekerja

Karyawan yang berkeinginan untuk melakukan pindah kerja, akan lebih malas bekerja karena orientasi karyawan ini adalah bekerja ditempat lainnya yang dipandang lebih mampu memenuhi semua keinginan karyawan yang bersangkutan.

3. Peningkatan terhadap pelanggaran tata tertib kerja

Berbagai pelanggaran terhadap tata tertib dalam lingkungan pekerjaan sering dilakukan karyawan yang ingin melakukan turnover. Karyawan lebih sering meninggalkan tempat kerja disaat jam kerja sedang berlangsung maupun berbagai bentuk pelanggaran lainnnya.

4. Peningkatan protes karyawan

Karyawan yang berkeinginan untuk melakukan pindah kerja, lebih sering melakukan protes terhadap kebijakan kebijakan perusahaan kepada atasan. Materi protes yang ditekankan biasanya berhubungan dengan balas jasa atau aturan lainnya yang tidak sependapat dengan keinginan karyawan.

Ada beberapa komponen yang mempengaruhi karyawan dalam memutuskan apakah akan bertahan atau meninggalkan perusahaan. Komponen tersebut adalah sebagai berikut

1. Komponen organisasional,hal yang menyangkut strategi perusahaan dalam MSDM dan keamanan kerja karyawan (job security).

2. Hubungan karyawan, meliputi perlakuan yang adil dan hubungan antar rekan kerja. Peluang karir, meliputi perencanaan karir.

3. Penghargaan, meliputi gaji, tunjangan dan bonus (kompensasi).

4. Rancangan tugas dan pekerjaan, kondisi kerja dan tanggung jawab kerja. 


\section{Budaya Organisasi}

Menurut Shaliha (2017), Budaya organisasi merupakan seperangkat nilainilai, keyakinan,dan sikap utama yang diberlakukan di antara anggota organisasi. Budaya yang dapat menyesuaikan serta mendorong keterlibatan karyawan dapat memperjelas tujuan dan arah strategi organisasi serta yang selalu menguraikan dan mengajarkan nilai - nilai dan keyakinan organisasi,dapat membantu organisasi mencapai pertumbuhan penjualan,pengembalian modal, keuntungan, mutu dan kepuasan pelanggan yang lebih tinggi. Menurut Yani (2017), menyatakan konsep dari suatu budaya organisasi adalah informalisasi dari satuan nilai dan norma sebagai alat kontrol bagi langkah-langkah karyawan dan kelompoknya di dalam organisasi untuk berinteraksi secara agresif, cepat dan mudah dengan lainnya,serta dengan orang diluar organissasi sebagai pelanggan dan pemasok. Menurut Pratama (2012), menyatakan konsep dari suatu budaya organisasi adalah informalisasi dari satuan nilai dan norma sebagai alat kontrol bagi langkah langkah karyawan dan kelompoknya di dalam organisasi untuk berinteraksi secara agresif, cepat dan mudah dengan lainnya, serta dengan orang diluar organissasi sebagai pelanggan dan pemasok. Menurut Wicaksono (2017), Budaya organisasi merupakan gaya dan cara hidup dari suatu organisasi yang merupakan pencerminan dari nilai-nilai atau kepercayaan yang dianut oleh seluruh anggota organisasi, budaya organisasi adalah pola kepercayaan, nilai, ritual, mitos para anggota suatu organisasi yang mempengaruhi perilaku semua individu dan kelompok di dalam organisasi. Budaya oganisasi dalam suatu organisasi yang satu dapat berbeda dengan yang ada dalam organisasi yang lain. Budaya organisasi menunjukkan ciri-ciri, sifat, atau karakteristik tertentu yang menunjukkan kesamaannya.

\section{Kompensasi Non Finansial}

Menurut Taringan (2017), Kompensasi Non Finansial merupakan imbalan dalam bentuk kepuasan seseorang yang diperoleh dari pekerjaan itu sendiri, atau dari lingkungan baik secara fisik atau psikologis dimana orang tersebut bekerja. Ciri dari kompensasi non finansial ini meliputi kepuasan yang didapat dari pelaksanaan tugas - tugas yang bermakna yang berhubungan dengan pekerjaan. Menurut Habibi (2013), Kompensasi non finansial adalah segala bentuk penghargaan yang diberikan oleh perusahaan dalam bentuk bukan finansial atau bukan uang. Kompensasi non finansial terdiri dari kepuasan yang diperoleh seseorang dari pekerjaan itu sendiri, atau dari lingkungan psikologis, dan atau fisik dimana orang itu bekerja. Menurut Eduard (2015), kompensasi non finansial adalah imbalan yang diberikan oleh perusahaan yang tidak berupa uang atau kepuasan yang diperoleh dari pekerjaaan itu sendiri dan dari lingkungan fisik atau psikologis dari tempat seorang bekerja dan sejumlah ganjaran yang bermaksud untuk memberikan rasa tenang bagi pekerja dan anggota keluarganya. Menurut Kogoya (2015), kompensasi non-finansial adalah kepuasan yang diterima seseorang dari pekerjaan itu sendiri atau dari lingkungan psikologis dan atau fisik tempat orang tersebut bekerja. Selanjutnya kompensasi non-finansial dibagi menjadi dua macam yaitu yang berhubungan dengan pekerjaan dan yang berhubungan dengan lingkungan kerja.

Ada beberapa jenis kompensasi non finansial yaitu (Simamora, 2006:448): 


\section{Pekerjaan}

Pekerjaaan merupakan tugas atau tanggung jawab yang diberikan kepada karyawan. kompensasi pekerjaan ini terdiri dari :
a. Tugas-tugas yang diberikan menarik bagi karyawan
b. Tantangan didalam pekerjaan sehingga karyawan dapat bekerja dengan penuh motivasi
c. Adanya tanggung jawab yang dibebankan kepada seorang karyawan
d. Adanya pengakuan dari perusahaan akan pekerjaan yang telah dikerahkan oleh karyawan

\section{Lingkungan kerja}

Lingkungan kerja merupakan suasana atau kondisi didalam pekerjaan seorang karyawan. lingkungan ini terdiri dari :

a. Kebijakan yang dikeluarkan oleh perusahaan yang akan mendukung suasana kerja

b. Supervise dari pemimpin yang berkompeten

c. Rekan kerja yang menyenangkan sehingga tercipta suasana kondusif

d. Lingkungan kerja yang nyaman yang akan membuat karyawan betah untuk bekerja

\section{Job Insecurity}

Menurut Sandi (2014), job insecurity merupakan cerminan derajat kepada karyawan yang merasakan pekerjaan mereka terancam dan merasakan ketidakberdayaan untuk melakukan segalanya tentang itu. Kondisi ini muncul karena banyaknya pekerjaan dengan status kontrak maupun outsourcing yang cukup marak diterapkan oleh perusahaan. Makin banyaknya pekerjaan dengan durasi waktu sementara atau tidak permanen, menyebabkan semakin banyaknya karyawan yang mengalami job insecurity.

Menurut Kurniawati (2017), job insecurity dapat didefinisikan sebagai kondisi yang berhubungan dengan rasa takut seseorang akan kehilangan pekerjaannya atau prospek akan demosi atau penurunan jabatan serta berbagai ancaman lainnya terhadap kondisi kerja yang berasosiasi menurunnya kesejahteraan secara psikologis dan menurunnya kepuasan kerja. Dan faktor yang mempengaruhi ketidakamanan kerja (job insecurity) dipengaruhi oleh lingkungan kerja yang meliputi lingkungan kerja fisik dan lingkungan kerja psikis, kondisi di luar lingkungan kerja, dan diri pribadi.

Menurut Aswad (2011), Job insecurity adalah sumber stress.Dalam penelitiannya, Ashford mengkonseptualisasikan job insecurity sebagai suatu sumber stress yang melibatkan ketakutan, kehilangan potensi dan kecemasan. Salah satu akibat dari stress tersebut adalah dalam bentuk permasalahan somatis seperti tidak bisa tidur dan kehilangan nafsu atau selera makan. Stress sendiri mempunyai definisi suatu perasaan yang menekan atau rasa tertekan yang dialami karyawan dalam menghadapi pekerjaannya.

Menurut Halungunan (2015), job insecurity sebagai kondisi psikologis seseorang (karyawan) yang menunjukkan rasa bingung atau 
merasa tidak aman dikarenakan kondisi lingkungan yang berubah-ubah (perceived impermanance). Kondisi ini muncul karena banyaknya jenis pekerjaan yang sifatnya sesaat atau pekerjaan kontrak. Makin banyaknya jenis pekerjaan dengan durasi waktu yang sementara atau tidak permanen menyebabkan semakin banyaknya karyawan yang mengalami job insecurity.

\section{METODE PENELITIAN \\ Jenis Penelitian}

Jenis Penelitian yang digunakan pada penelitian ini adalah penelitian kuantitatif. Menurut Suryani \& Hendryadi (2015) penelitian kuantitatif adalah penelitian menggunakan analisis data yang berbentuk numerik/angka dengan menggunakan model konseptual. Penelitian ini digunakan untuk meneliti sample atau populasi tertentu, dengan tujuan untuk mengembangkann dan menggunakan model matematis, teori dan/atau hipotesis yang berkaitan dengan fenomena yang diselidiki oleh peneliti.

\section{Objek Penelitian}

Objek penelitian adalah suatu yang menjadi perhatian dalam suatu penelitian atau tempat / lokasi dimana seseorang meneliti sebuah riset. Pada penelitian ini yang menjadi objek penelitian adalah PT. BPR Cincin Permata Andalas cabang Padang.

\section{Populasi}

Menurut Sugiyono (2011), Populasi adalah obyek atau subyek yang memiliki karakteristik tertentu yang telah ditetapkan oleh peneliti untuk dipelajari dan kemudian diambil kesimpulan. Oleh karena itu, dapat disimpulkan bahwa populasi merupakan keseluruhan subjek ataupun objek yang memiliki karakteristik berbeda dan bisa diteliti atau diamati. Populasi dalam penelitian ini adalah seluruh karyawan PT.Bank Rakyat Indonesia yang berjumlah 30 orang, pada penelitian ini peneliti hanya meneliti berdasarkan kriteria karyawan tetap. Dimana jumlah karyawan tetap pada PT. BPR Cincin Permata Andalas cabang Padang sebanyak 30 orang. dimana disini akan menguji tentang pengaruh Budaya organisasi, kompensasi non financial, dan job insecurity terhadap turnover intention.

\section{Sampel}

Sampel merupakan bagian dari jumlah yang dimiliki populasi, untuk itu sampel yang diambil harus betul-betul mewakili (Sugiyono, 2015) . Oleh karena itu, sampel harus bisa mewakili keseluruhan subjek ataupun objek dalam penelitian. Dalam penelitian ini teknik pengambilan sampel yang digunakan adalah sampling jenuh dimana teknik ini menggunakan seluruh populasi menjadi sampel. Sampel yang digunakan sebanyak 30 karyawan pada PT. BPR Cincin Permata Andalas cabang Padang.

\section{Teknik Analisis Data}

\section{Uji Validitas}

Menurut Sujarweni (2016), uji validitas digunakan untuk mengetahui kelayakan butir-butir pertanyaan atau pernyataan dari kuesioner (instrument) penelitian dalam mendefenisikan suatu variabel. Daftar pertanyaan atau penyataan ini pada umumnya mendukung suatu kelompok variabel tertentu. Uji validitas sebaiknya dilakukan paada setiap butir pernyataan di uji validitasnya, dengan membandingkan antara $r$ hitung dengan $\mathrm{r}$ tabel dimana $\mathrm{df}=\mathrm{n}-2$ dengan sig 5\%. Jika $\mathrm{r}$ tabel $>\mathrm{r}$ hitung maka dikatakan valid. Untuk melihat korelasi dalam validitas maka digunakanlah factor analysis. Factor analysis merupakan metode multivariat yang digunakan untuk menganalisis variabelvariabel yang diduga memiliki ketertarikan satu sama lain. Factor analysis yang digunakan dalam penelitian ini adalah EFA (Exploratory Factor Analysis) dan CFA (Confirmatory Factor Analysis). 


\section{Uji Reliabilitas}

Menurut Sujarweni (2016), Reliabilitas merupakan ukuran suatu kestabilan dan konsistensi responden dalam menjawab hal yang berkaitan dengan butir-butir pertanyaan atau pernyataan yang merupakan dimensi suatu variabel dan disusun dalam suatu bentuk kuesioner (instrument). Alat untuk mengukur reliabilitas adalah Cronbach Alpha. Sebuah instrument dikatakan reliable adalah apabila koefisien reliabelnya $\geq 0,7$, apabila koefisien reliabelnya nya $<0,7$ maka sebuah instrument tersebut dikatakan tidak reliabel.

\section{Uji TCR (Tingkat Capaian Responden)}

Menurut Suharsimi (2002) total capaian responden merupakan suatu ukuran untuk menghitung masing-masing kategori jawaban dari deskriptif variabel, maka dapat dihitung dengan menggunkan rumusan:

$$
T C R=\frac{\text { Skor tiap item }}{\text { Skor ideal item yang dihitung }} \times 100 \%
$$

Keterangan :

TCR $=$ Tingkat Capaian Responden

Untuk menginterprestasikan jawaban responden terhadap pertanyaa yang diajukan, sebagai acuannya tabel kriteria pengklasifikasikan rata-rata jawaban responden sebagai berikut :
a. $81-100 \%=$ sangat baik
b. $\quad 61-80 \%=$ baik
c. $\quad 41-60 \%=$ kurang baik
d. $21-40 \%=$ tidak baik
e. $<20 \%=$ sangat tidak baik

Uji Asumsi Klasik

Uji Normalitas

Menurut Sujarweni (2016), Uji normalitas bertujuan untuk mengetahui distribusi data dalam variabel yang akan digunakan dalam penelitian. Data yang baik dan layak digunakan dalam penelitian adalah data yang memiliki distribusi normal. Normalitas data dapat dilihat dengan menggunakan uji Normal Kolmogorov - Smirnov.

Uji Multikolinearitas

Menurut Gujarati (2012: 432), Pengujian Multikolinearitas dilihat dari besaran VIF (Variance Inflation Factor) dan tolerance. Tolerance mengukur variabel independen yang terpilih yang tidak dijelaskan oleh variabel independen lainnya. Jadi nilai tolerance yang rendah sama dengan nilai VIF tinggi (karena VIF $=1 /$ tolerance). Nilai cut off yang umum dipakai untuk menunjukkan adanya multikolinearitas adalah nilai tolerance $>0,1$ atau sama dengan nilai VIF $<10$ (Setiawan, 2014).

Heteroskedastisitas

Menurut Sujarweni (2016), Heteroskedastisitas bertujuan untuk menguji terjadinya perbedaan variance residual sautu periode pengamatan ke periode pengamatan yang lain. Cara memprediksi ada tidaknya heteroskedastisitas pada suatu model dapat dilihat dengan pola gambar Scatterplot, regresi yang tidak terjadi heteroskedastisitas jika:

1) Titik-titik data menyebar diatas dan dibawah atau disekitar angka 0 .

2) Titik-titik data tidak mengumpul hanya diatas atau dibawah saja.

3) Penyebaran titik-titik data tidak boleh membentuk pola bergelombang melebar kemudian menyempit dan melebar kembali.

4) Penyebaran titik-titik data tidak berpola.

Menurut Sujarweni (2016), uji glejser menyarankan untuk meregresikan nilai absolut residual terhadap variabel bebas. Apabila signifikan probabilitasnya $>0,05$ atau $5 \%$ maka tidak terjadi heteroskedastisitas tetapi jika tingkat signifikan probabilitasnya < 
0,05 atau $5 \%$ maka terjadi heteroskedastisitas. Adapun persamaan uji glejser adalah sebagai berikut:

\section{Uji Glejser}

$$
|\mathrm{Ut}|=\alpha+\beta \mathrm{Xt}+\mathrm{vi}
$$

Salah satu cara untuk melihat adanya problem heteroskedastisitas adalah dengan menggunakan uji glejser, dengan ketentuan jika nilai signifikasinya > 0,05 dapat disimpulkan model regresi tidak terjadi masalah heteroskedastisitas.

\section{Regresi Berganda}

Menurut Sujarweni (2016), regresi berganda bertujuan untuk menguji pengaruh antara variabel bebas (independent) dengan variabel (dependent). Regresi berganda memiliki satu variabel dependen dan lebih dari satu variabel independen. Model persamaan analisis berganda adalah sebagai berikut:

$\mathrm{Y}=\mathrm{a}+\mathrm{b}_{1} \mathrm{X}_{1}+\mathrm{b}_{2} \mathrm{X}_{2}+\mathrm{b}_{3} \mathrm{X}_{3}+\mathrm{e}$

Keterangan:

$\mathrm{Y}=$ Kesejahteraan masyarakat

$\mathrm{a}=$ Konstanta

$\mathrm{b}=$ koefisien Regresi

$\mathrm{X}_{1}=$ Budaya Organisasi

$\mathrm{X}_{2}=$ Kompensasi Non Finansial

$\mathrm{X}_{3}=$ Job Insecurity

$\mathrm{e}=$ error

\section{Uji Statistik / Uji Hipotesis}

T-Test (Uji Statistik)

Menurut Ghozali (2014), Uji beda t-test digunakan untuk menguji seberapa jauh pengaruh variabel independen yang digunakan dalam penelitian ini secara individual dalam menerangkan variabel dependen secara parsial. Dasar pengambilan keputusan digunakan dalam uji $\mathrm{t}$ adalah sebagai berikut:

1) Jika nilai probabilitas signifikan $>0,05$ maka hipotesis ditolak. Hipotesis ditolak mempunyai arti bahwa variabel independen tidak berpengaruh signifikan terhadap variabel dependen.

2) Jika nilai probabilitas signifikan $<0,05$ maka hipotesis diterima. Hipotesis tidak dapat ditolak mempunyai arti bahwa variabel independen berpengaruh signifikan terhadap variabel dependen.

\section{Koefisien Determinasi $\left(\mathbf{R}^{2}\right)$}

Menurut Ghozali (2014), Koefisien determinasi $\left(R^{2}\right)$ merupakan alat yang digunakan untuk mengukur seberapa jauh pengaruh semua variabel independen mempengaruhi variabel dependen. Nilai koefisien determinasi adalah 0 atau 1 . Nilai $R^{2}$ yang kecil berarti kemampuan variabel-variabel independen dalam menjelaskan variasi variabel dependen amat terbatas. Dan sebaliknya nilai yang mendekati 1 berarti variabelvariabel independen memberikan hampir semua informasi yang dibutuhkan untuk memprediksi variabel-variabel dependen.

$$
\begin{aligned}
& \mathrm{KD}=\mathrm{R}^{2} \times 100 \% \\
& \text { Keterangan: } \\
& \mathrm{KD} \quad=\text { Koefisien Determinasi } \\
& \mathrm{R} \quad=\text { Koefisien Korelasi }
\end{aligned}
$$




\section{HASIL DAN PEMBAHASAN \\ Analisis Regresi Linear Berganda}

Analisis regresi linear berganda digunakan untuk mengukur kekuatan hubungan antara dua variabel atau lebih, dan juga menunjukkan arah hubungan antara variabel dependen dengan variabel independen. Hasil analisis regresi berganda yang diolah dengan SPSS dapat dilih at pada tabel 1.

\section{Tabel 1}

Hasil Uji Regresi Linear Berganda

Coefficients $^{\mathrm{a}}$

\begin{tabular}{|c|c|c|c|c|c|c|}
\hline \multirow{2}{*}{\multicolumn{2}{|c|}{ Model }} & \multicolumn{2}{|c|}{ Unstandardized Coefficients } & \multirow{2}{*}{$\frac{\begin{array}{c}\text { Standardized } \\
\text { Coefficients }\end{array}}{\text { Beta }}$} & \multirow[b]{2}{*}{$\mathrm{t}$} & \multirow[b]{2}{*}{ Sig. } \\
\hline & & $\mathrm{B}$ & Std. Error & & & \\
\hline \multirow[t]{4}{*}{1} & (Constant) & -4.211 & 3.654 & & -1.152 & .260 \\
\hline & $\begin{array}{l}\text { Bo : budaya } \\
\text { organisasi }\end{array}$ & -001 & .252 & .001 & -.005 & .996 \\
\hline & $\begin{array}{l}\text { Knf : kompensasi non } \\
\text { finansial }\end{array}$ & -599 & .256 & .407 & 2.334 & .028 \\
\hline & Jo : job insecurity & 795 & .252 & .537 & 3.157 & .004 \\
\hline
\end{tabular}

Sumber : Data SPSS 16 (Data diolah tahun 2018)

Berdasarkan hasil regresi yang didapat maka dibuat persamaan linear berganda sebagai berikut :

$\mathrm{Y}=-4.211+-001(\mathrm{X} 1)+-599(\mathrm{X} 2)+795(\mathrm{X} 3)+\mathrm{e}$

Persamaan regresi linear berganda diatas mempunyai arti sebagai berikut :

1. Konstanta mempunyai nilai positif sebesar -4.211 . Hal ini berarti apabila budaya organisasi, kompensasi non finansial dan job insecurity PT. BPR cincin permata andalas Padang bernilai nol, maka turnover karyawan masih bernilai tetap -4.221.

2. Nilai koefisien regresi budaya organisasi adalah 0,001 artinya apabila budaya organisasi meningkat sebesar satu satuan, maka turnover intention berkurang 0,001 .

3. Nilai koefisien regresi kompensasi non finansial adalah $-0,599$ artinya apabila kompensasi non finansial meningkat satu satuan maka turnover intention berkurang $-0,599$.

4. Nilai koefisien regresi job insecurity adalah $-0,795$ artinya apabila job insecurity meningkat satu satuan maka turnover intention berkurang 0,795 .

\section{Uji F}

Uji $F$ ini digunakan untuk dapat mengetahui apakah semua variabel independen yang digunakan secara bersama-sama mempunyai pengaruh terhadap variabel dependennya. Berikut hasil uji f budaya organisasi, kompensasi non financial dan kesempatan promosi terhadap turnover intention dikemukakan pada tabel 2 . 
Tabel 2

Hasil Uji F

ANOVA $^{\mathrm{b}}$

\begin{tabular}{|c|c|c|c|c|c|c|}
\hline \multicolumn{2}{|c|}{ Model } & Sum of Squares & Df & Mean Square & $\mathrm{F}$ & Sig. \\
\hline 1 & Regression & 729.750 & 3 & 243.250 & 31.245 & $0,000^{\mathrm{a}}$ \\
\hline & Residual & 202.416 & 26 & 7.785 & & \\
\hline & Total & 932.167 & 29 & & & \\
\hline
\end{tabular}

Sumber : Data SPSS 16 (Data diolah tahun 2018

Dari tabel 2 diketahui hasil uji f sebesar 31.254 dan nilai signifikan sebesar 0,000 . Hal ini berarti nilai signifikan $\mathrm{f}$ sebesar $0,000<0,05$, menunjukkan variabel budaya organisasi,kompensasi non finansial dan job insecurity secara bersama-sama dapat menjelaskan variabel turnover intention.

Uji T

Untuk mengetahui pengaruh budaya organisasi, kompensasi non finansial, dan job insecurity terhadap turnover intention, maka dilakukan pengujian hipotesis melalui uji t dengan hasil sebagai berikut :

Tabel 3

Hasil Perhitungan Koefisien Regresi (Uji T)

Coefficients $^{\mathrm{a}}$

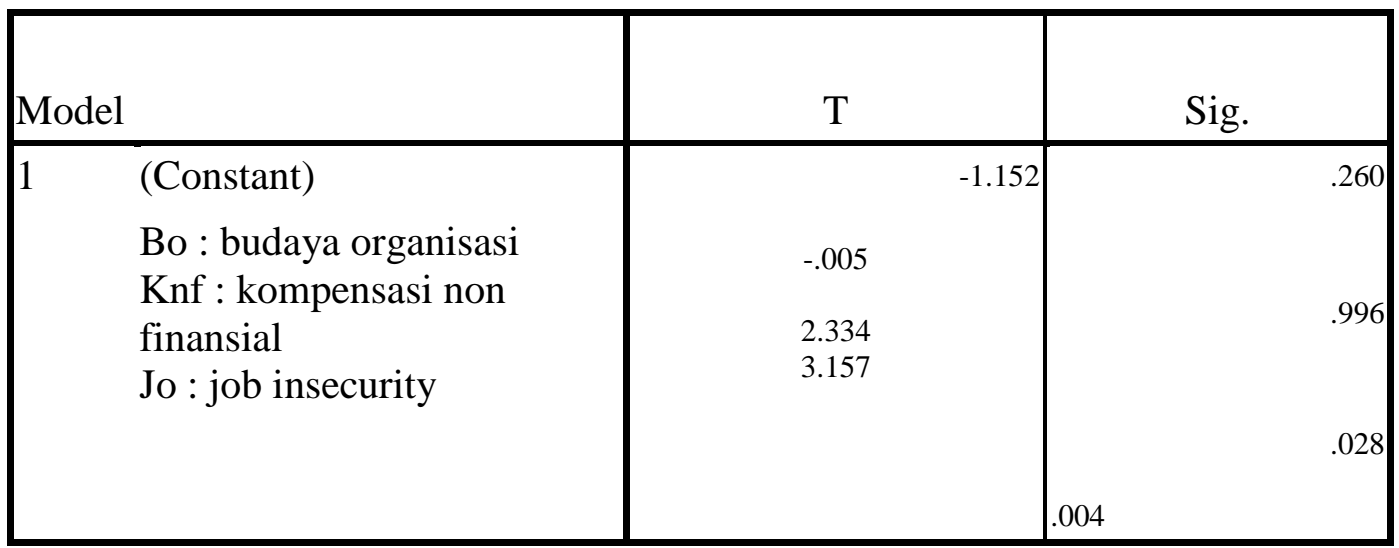

Sumber: Data SPSS 16 (Data diolah tahun 2018) berikut :

Berdasarkan hasil uji t pada tabel 3 dapat dilkakukan analisa sebagai

1. Hasil uji t budaya organisasi terhadap turnover intention diperoleh thitung $(-005)<\mathrm{t}$ tabel $(1,701)$ dan nilai signifikansi sebesar 996. Hal ini menunjukkan adanya pengaruh negatif dan tidak signifikan (996 < 0,05). Sehingga menerima hipotesis H1 yang menyatakan budaya organisasi berpengaruh negatif dan signifikan terhadap turnover intention. Sehingga menolak hipotesis yang menyatakan budaya organisasi berpengaruh negatif dan signifikan terhadap turnover intention

2. Hasil uji t kompensasi non financial terhadap turnover intention diperoleh thitung $(-2,334)>\mathrm{t}$ tabel $(1,701)$ dan nilai signifikansi 
Uji $\mathbf{R}^{2}$

sebesar 0,028 . Hal ini menunjukkan adanya pengaruh yang positif dan signifikan $(0,028>0,05)$.

3. Hasil uji t kompensasi job insecurity terhadap turnover intention diperoleh thitung $(3,157)>\mathrm{t}$ tabel $(1,701)$ dan nilai signifikansi sebesar 0,004. Hal ini menunjukkan adanya pengaruh yang positif dan signifikan $(0,004>0,05)$.

Hasil koefisien determinasi $\left(\mathrm{R}^{2}\right)$ pengaruh stress kerja dan kesempatan promosi terhadap turnover intention dikemukakan pada tabel 4

Tabel 4

Hasil uji Koefisien Regresi Determinasi $\left(\mathbf{R}^{2}\right)$

Model Summary

\begin{tabular}{|l|r|c|r|r|}
\hline Model & $\mathrm{R}$ & R Square & Adjusted R Square & $\begin{array}{c}\text { Std. Error of the } \\
\text { Estimate }\end{array}$ \\
\hline 1 & $.885^{\mathrm{a}}$ & 783 & 758 & 2.790 \\
\hline
\end{tabular}

Sumber : Data SPSS 16 (Data diolah tahun 2018)

Besarnya koefisien determinasi dapat dilihat pada Adjusted $R$ Square adalah sebesar 0,717, yang mempunyai arti bahwa turnover intention dijelaskan oleh variabel budaya organisasi, kompensasi non finansial, dan job insecurity sebesar $75,8 \%$, sedangkan sebesar $24,2 \%$ dijelaskan oleh variabel lain yang tidak diteliti dalam penelitian ini.

\section{PEMBAHASAN}

Pengaruh budaya organisasi, kompensasi non finansial, dan job insecurity terhadap turnover intention

Berdasarkan hasil pengujian hipotesis pertama, ditemukan bahwa variable berpengaruh negatif dan tidak signifikan terhadap turnover intention pada PT. BPR Cincin Permata Andalas Padang. Berdasarkan hasil uji t pada variabel budaya organisasi sebesar $-0,005$ dan tidak signifikansinya sebesar 0, 996 yang lebih kecil dari 0,05. Hal ini dapat diartikan bahwa variabel budaya organisasi berpengaruh negatif dan tidak signifikan terhadap turnover intention, dengan demikian, hipotesis pertama (H1) dalam penelitian ini yang menyatakan bahwa budaya organisasi berpengaruh negatif dan tidak signifikan terhadap turnover intention pada CV. Anisa Fadly Kabupaten Padang Pariaman, dinyatakan ditolak.

budaya sebagai suatu asumsi-asumsi dan keyakinan-keyakinan dasar yang dirasakan bersama oleh para anggota dari suatu kelompok dan organisasi. Dengan demikian budaya organisasi dapat diartikan sebagai suasana atau keadaan dalam suatu kelompok kerjasama antara orang-orang tergabung di dalamnya untuk mencapai tujuan bersama. Turnover intention merupakan keadaan dimana karyawan memiliki keinginan untuk keluar dari organisasi karena suatu alasan.

Berdasarkan hasil pengujian hipotesis kedua, ditemukan bahwa variabel kompensasi non finansial berpengaruh positif dan signifikan terhadap turnover intention pada PT.BPR Cincin Permata Andalas Padang . Berdasarkan hasil uji t variabel kompensasi non finansial sebesar 2.334 dan signifikansinya sebesar 0,028 yang lebih besar dari 0,05 . Hal ini dapat diartikan bahwa variabel 
kompensasi non finansial berpengaruh positif dan signifikan terhadap turnover intention, dengan demikian, hipotesis kedua $(\mathrm{H} 2)$ dalam penelitian ini yang menyatakan bahwa kompensasi non finansial berpengaruh positif dan signifikan terhadap turnover intention pada PT. BPR Cincin Permata Andalas dapat diterima.

Berdasarkan hasil pengujian hipotesis kedua, ditemukan bahwa variabel job insecurity berpengaruh positif dan signifikan terhadap turnover intention pada PT.BPR Cincin Permata Andalas Padang . Berdasarkan hasil uji t variabel job insecurity sebesar 3.157 dan signifikansinya sebesar 0,004 yang lebih besar dari 0,05 . Hal ini dapat diartikan bahwa variabel kompensasi non finansial berpengaruh positif dan signifikan terhadap turnover intention, dengan demikian, hipotesis kedua $(\mathrm{H} 3)$ dalam penelitian ini yang menyatakan bahwa job insecurity berpengaruh positif dan signifikan terhadap turnover intention pada PT. BPR Cincin Permata Andalas dapat diterima.

Hal ini bermakna tingkat turnover intention akan tetap terjadi pada PT. BPR cincin permata andalas padang, meskipun ada atau tidaknya budaya organisasi di perusahaan tersebut. Penelitian sejenis ini sebelumya juga dilakukan oleh (Agus, 2011) menjelaskan bahwa budaya organisasi berpengaruh negatif dan tidak signifikan terhadap turnover inention pada karyawan Hotel Bintang Empat Di Surabaya.

\section{SIMPULAN}

1. Berdasarkan hasil pengujian hipotesis pertama, ditemukan bahwa variable berpengaruh negatif dan tidak signifikan terhadap turnover intention pada PT. BPR Cincin Permata Andalas Padang . Berdasarkan hasil uji t pada variabel budaya organisasi sebesar -0,005 dan tidak signifikansinya sebesar 0, 996 yang lebih kecil dari 0,05. Hal ini dapat diartikan bahwa variabel budaya organisasi berpengaruh negatif dan tidak signifikan terhadap turnover intention, dengan demikian, hipotesis pertama (H1) dalam penelitian ini yang menyatakan bahwa budaya organisasi berpengaruh negatif dan tidak signifikan terhadap turnover intention.

2. Berdasarkan hasil pengujian hipotesis kedua, ditemukan bahwa variabel kompensasi non finansial berpengaruh positif dan signifikan terhadap turnover intention pada PT.BPR Cincin Permata Andalas Padang. Berdasarkan hasil uji t variabel kompensasi non finansial sebesar 2.334 dan signifikansinya sebesar 0,028 yang lebih besar dari 0,05 . Hal ini dapat diartikan bahwa variabel kompensasi non finansial berpengaruh positif dan signifikan terhadap turnover intention, dengan demikian, hipotesis kedua (H2) dalam penelitian ini yang menyatakan bahwa kompensasi non finansial berpengaruh positif dan signifikan terhadap turnover intention pada PT. BPR Cincin Permata Andalas dapat diterima.

3. Berdasarkan hasil pengujian hipotesis ketiga, ditemukan bahwa variabel job insecurity berpengaruh positif dan signifikan terhadap turnover intention pada PT.BPR Cincin Permata Andalas Padang. Berdasarkan hasil uji t variabel job insecurity sebesar 3.157 dan signifikansinya sebesar 0,004 yang lebih besar dari 0,05. Hal ini dapat diartikan bahwa variabel kompensasi non 
finansial berpengaruh positif dan signifikan terhadap turnover intention, dengan demikian, hipotesis kedua (H3) dalam penelitian ini yang menyatakan bahwa job insecurity berpengaruh positif dan signifikan terhadap turnover intention pada PT. BPR Cincin Permata Andalas dapat diterima.

4. Besarnya koefisien determinasi dapat dilihat pada Adjusted $R$ Square adalah sebesar 0,717, yang mempunyai arti bahwa turnover intention dijelaskan oleh variabel budaya organisasi, kompensasi non finansial, dan job insecurity sebesar $75,8 \%$, sedangkan sebesar $24,2 \%$ dijelaskan oleh variabel lain yang tidak diteliti dalam penelitian ini.

\section{DAFTAR PUSTAKA}

Aldi, Y., \& Susanti, F. (2019). Pengaruh Stress Kerja Dan Motivasi Kerja Terhadap Prestasi Kerja Karyawan Pada PT. Frisian Flag Indonesia Wilayah Padang. https://doi.org/10.31227/osf.io/et4rn

Fendi, Z., \& Susanti, F. (2018). Pengaruh Kepuasan Kerja Terhadap Turnover Intention Dengan Komitmen Organisasi Sebagai Variabel Intervening Pada CV. Belibis Pariaman. https://doi.org/10.31227/osf.io/wumgx

Ghozali, I. (2016). Aplikasi Analisis Multivariate dengan Program IBM SPSS 20. Semarang: Badan Penerbit Universitas Diponegoro.

Junaidi, R., \& Susanti, F. (2019). Pengaruh Gaya Kepemimpinan Dan Budaya Organisasi Terhadap Kinerja Pegawai Pada UPTD Baltekkomdik Dinas Pendidikan Provinsi Sumatera Barat. https://doi.org/10.31227/osf.io/bzq75

Kurniawati, D. E. (2017). Analisis Pengaruh Kompensasi, Job Insecurity dan Kepuasan Kerja terhadap Turnover Intention pada Karyawan BTN Syariah Kantor Cabang Semarang. Institut Agama Islam Negeri.

Mayliza, R. (2019). Pengaruh Kompensasi Finansial, Lingkungan Kerja Dan Motivasi Kerja Terhadap Kinerja Pegawai Pada Kantor PDAM Kota Payakumbuh. https://doi.org/10.17605/OSF.IO/DZXAF

Mokodompit, W. (2016). Pengaruh Budaya Organisasi dan Kepuasan Kerja terhadap Kinerja Karyawan PT. Pos Indonesia (Persero) Cabang Makassar. Universitas Negeri Makassar.

Notoprawiro, Fi. R. (2016). Analisis Pengaruh Lingkungan Kerja dan Stres Kerja terhadap Turnover Intention Karyawan (Studi Kasus pada PT. Graha Sumber Berkah). Universitas Islam Negeri Syarif Hidayatullah.

Nugroho, D. A. D., Handayani, S. R., \& Saifi, M. (2014). Pengaruh Drop Box dan E-Filling terhadap Kepatuhan Penyampaian SPT Tahunan PPh, 1, 44-55. 
Rikardo, T., \& Susanti, F. (2019). Pengaruh Job Insecurity, Dan Beban Kerja Terhadap Stres Kerja Pada PT Garda Total Security Padang. https://doi.org/10.31227/osf.io/pfe72

Sandi, F. M. (2014). Analisis Pengaruh Kompensasi dan Job Insecurity terhadap Turnover Intention ( Studi Pada Guru SDIT Asy-Syaamil Bontang ). Universitas Diponegoro.

Sugiyono. (2011). Metode Penelitian Kuantitatif, Kualitatif dan R\&D. Bandung: Alfabeta.

Suryani, \& Hendryadi. (2015). Metode Riset Kuantitatif. (Suwito, Ed.) (Pertama). Jakarta: Prenadamedia Group.

Taringan, N. B. (2017). Pengaruh Kompensasi Finansial dan Kompensasi Non Finansial terhadap Kinerja Karyawan pada PT. Pratama Widya Batam. Akademi Akuntansi Permata Harapan Batam.

(Ghozali, 2011)Ghozali, I. (2011). Aplikasi Analisis Multivariate Dengan Program IBM SPSS 20. In book (pp. 1-298). Semarang: Badan Penerbit Universitas Diponegoro.

Latifah, S. W., Akuntansi, S., \& Penjualan, H. P. (n.d.). Penerapan sistem pemasaran terpadu dan sistem informasi akuntansi pada sentra industri pengolahan berbasis kedelai, 1-11.

Safi'i, S. Z. (2015). Pengaruh Budaya Organisasi dan Komitmen Organisasi terhadap Turnover Karyawan pada PT. Massindo Sinar Pratama. TBK Manado, 3(1), 642-652.

Saputra, B. (2017). Pengaruh Budaya Organisasi, Kompensasi Non Finansial dan Job Insecurity terhadap Turnover Intention PT. Parit Padang Pekanbaru, $4(1), 806-815$.

Yudistira, D. S., \& Susanti, F. (2019). Pengaruh Motivasi Kerja Dan Budaya Kerja Terhadap Kinerja Karyawan Dinas Pemberdayaan Masyarakat Dan Desa, Pengendalian Penduduk Dan Keluarga Berencana Kabupaten Pesisir Selatan. https://doi.org/10.31227/osf.io/jk54m 